Research Article

Open Access

Ligita Priede, Dagnija Vigule

\title{
Teacher - Facilitator of Meaningful Learning in Preschool
}

DOI 10.1515/sigtem-2016-0020

\begin{abstract}
Activity is one of the key structural elements of free, independent and creative personality. Independence of child is closely related to cognitive activity and the need to satisfy it. Planning of pedagogical process in pre-school should be based on the fact, understanding that child is learning via voluntary investigating, doing and solving issues of a cognitive character. While in the middle of a learning process, child is not learning to remember certain facts, but cognises oneself and own abilities. By keeping the balance between promotion of child's own discoveries and direct teaching, the teacher helps in finding answers to the many questions child has, thus promoting cognition and creative activity thereof. If an adult tells pre-schooler what he should or should not do and makes him to accomplish certain tasks, cognition activity of child is not satisfied and learning has not taken place. Moreover, if the tasks are the same and given to all children in the same time, child's individuality, development level of each particular child and freedom of choice are disregarded. This research is aimed at theoretical and empirical study of preconditions for meaningful learning in preschool. The theoretical background of the research consists of findings about learning activities of pre-schoolers published by pedagogues and psychologists known both in Latvia and abroad. Within the framework of the issue to be researched, the following was analysed: experience of preschool teachers in divided into frequency and interpretation (by using descriptive and inferential statistics (IBM SPSS Statistics-v19.0)), and experience of pre-schoolers at older age when working with worksheets.
\end{abstract}

Keywords: pre-schooler, teacher, meaningful learning.

\section{Introduction}

In the present day, in both theory and practice, a lot of attention is devoted to the development or upbringing of free and creative personality. Independence and activity of child is one of the key structural elements of free, independent and creative personality. Independence of the child is closely related to cognitive activity and need to satisfy it. The child at a pre-school age is learning via investigating, doing and solving issues of a cognitive character. Through practical activities, the child not only learns about various things, natural objects, characteristics of natural, physical phenomena, but also sees simple connections and regularities. It is much more easier for the child to see the connections if learning takes place naturally, if child is allowed to investigate, work actively and directly, with no intermediaries. Cognition is formed and high results are achieved only through own investigations, trying and experiments. The more the child is engaged in particular activity, the longer is the span he is interested in it and the easier it is for the child to remember this experience.

When traditional learning (teaching) methods, i.e. the ones characteristic with 'information flow from the subject to person' (Bazens, 2008, 28), are used in the learning process, pedagogue is teaching content that is meaningless to the child, thus all the time spent for it is wasted. Planning of pedagogical process in

${ }^{\star}$ Corresponding author: Ligita Priede, Dagnija Vigule: Riga Teacher Training and Educational Management Academy, Latvia, E-mail: dagnija.vigule@rpiva.Iv 
pre-school should be based on the understanding that child is learning via voluntary investigating, doing and solving issues of a cognitive character. The issue is topical and significant in case a child perceives it as a problem to be solved. Topics interesting to teacher not always are appealing to child. However, it does not mean that child always does what he wants.

Bearing in mind children's interests, abilities and development of each individual child, teacher plans curriculum, by listening to children's ideas and questions (Geist, 2009). While in the middle of a learning process, the child is not learning to remember certain facts, but cognises oneself and own abilities, thus exploring the world (Bazens, 2008). By keeping the balance between promotion of child's own discoveries and direct teaching, the teacher helps in finding answers to the many questions the child has, thus promoting his cognition and creative activity. If an adult tells pre-schooler what he should or should not do and makes him to accomplish certain tasks already at the younger pre-school age, cognition activity of child is not satisfied and learning has not taken place. Moreover, if the tasks are the same and given to all children in the same time, child's individuality, development level of each child and freedom of choice are disregarded. Choice is of a major importance in the development of child's personality. The benefits of allowing a child to act freely by teaching to ask for help just when necessary, allowing the child to choose the activity, control time and place of the action are great and invaluable. It is of major significance for the child to recognise oneself as a personality having certain influence on the surrounding world.

\section{Aim of the Study}

The research aim of this study is theoretical and empirical study of pre-conditions for meaningful learning in pre-school.

\section{Materials and Methods}

The theoretical background for the research consists of findings about learning activities of pre-schoolers published by pedagogues and psychologists known both in Latvia and abroad. Within the framework of the issue to be researched, the following was analysed:

- Experience of pre-school teachers divided into frequency and interpretation (by using descriptive and inferential statistics (IBM SPSS Statistics-v19.0));

- Experience of pre-schoolers at older age when working with worksheets.

\section{Results}

Humanistic psychology emphasises that personality activity is encouraged, driven and regulated by hierarchically arranged motives and not by external stimulus (Behaviourists theory). In all his activities, the child is guided by his own needs, motives (Montessori, 1965; Выготский, 2003; Liegeniece, 1992; Бордовская, Реан, 2000), оwn subjective vision of the world regulating his attitude towards human, universal values (Liegeniece, 1992), since actual source of the motives is located in the child. The aim of the activity is created, defined by the individual; therefore, it cannot be imposed on the child, cannot be changed forcefully; child for the action is motivated by his own individuality (Eriksons, 1998). Nowadays, it is believed that at pre-school age, there are several dominating groups of motives influencing activity of the child (Вилюнас, 1990). Traditional motive groups of pre-schoolers are shown in the Figure 1.

Within the framework of the research on facilitation of meaningful learning of pre-schoolers in pedagogical process, only the motive groups related to the following are important:

1. Play process, playing. Learning activities in a form of games and plays allow the child to feel that he belongs somewhere, develops child's independence, autonomy, as well as facilitates physical, social and psychic development. Child is able to perceive learning as a play if he has an opportunity to choose the activity as well as time and place for it. 
2. Cognition motives. For exploration and learning, the child needs practical activity and real materials. Cognition activity of pre-schooler is facilitated by beginning active manipulating and feeling.

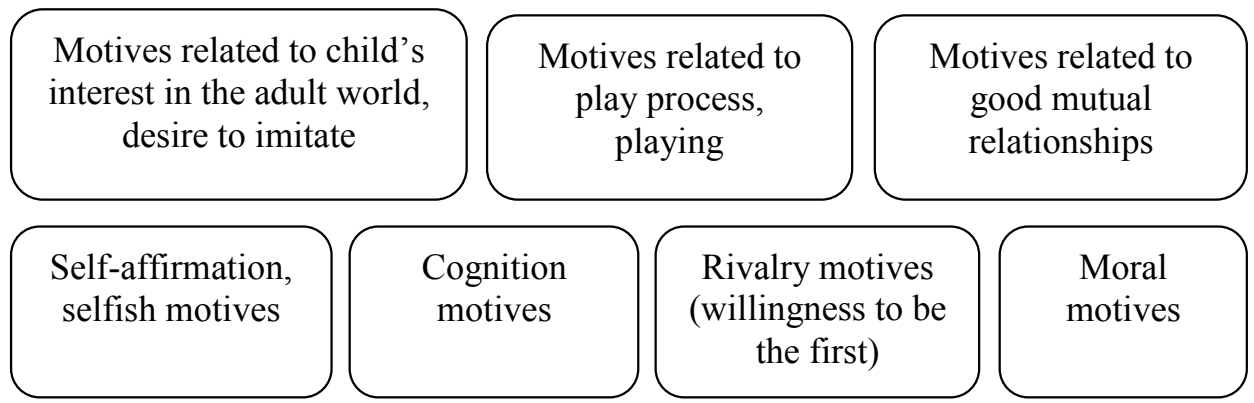

Figure 1. Typical motive groups of pre-schoolers (Вилюнас, 1990)

How much (if any) attention pedagogues devote to these motive groups in their daily work? What is the reason behind the lack of joy in attending kindergarten? Perhaps mainly due to the fact that child does not like the activities because of the complexity and incomprehensibility or monotony and vapidity thereof. The activities are not planned in a way to meet child's needs and interests.

In pre-school, all activities may be games, as playing for children is natural, unconstrained and meaningful activity. The most meaningful learning activity is when the child is engaged in it by not knowing that learning takes place. It is also of a major significance to ensure that the child is able to change the place, where the activity takes place, feel free and unlimited, continue the activity without direct guidance or involvement of the teacher. Each child learns new things at his own speed, phase, therefore teacher should take care to ensure that child has time and possibility to be engaged with the new game or material till he has discovered it completely. It is of a great significance that child has the opportunity to have suitable conditions for the activity, thus he will learn many new things (Geist, 2009). The main task of the teacher is to observe children in their activities and notice the moment, when child starts to lose interest, and react with changing the environment, thus keeping the attention of the child and providing a new challenge. It was important to find out, how it works in practice; do pedagogues plan pedagogical process bearing in mind child's needs and interests reflected within his play. How does pedagogue act if the child has to stop his play. By researching the situation in the real practice, 222 pre-school education teachers were interviewed. The responses are summarised in the Figure 2.

The results acquired show that, when planning the pedagogical process, the pedagogues do not always take into account the topical and individual needs of the child and base curriculum laid down in the Regulation No 533 of the Cabinet. The Regulation on the State Preschool Education Guidelines stipulates that playing is the main activity of the child at pre-school age, whereas form of work organisation - independent activity of the child and play-based lessons with integrated training content (Regulations No 533 of the Cabinet, 2012).

Only $4 \%$ of the teachers organise pedagogical process to ensure that the child is able to finish his play, $7.5 \%$ try to ensure that the child may finish his play. A pedagogue prioritising formation of a strong personality over implementation of a programme does not stop child's activity or play; he supports the child's perseverance in overcoming his problems and accomplishing tasks.

If a pedagogue understands the needs of the pre-schooler, he gives child time for his free choice and independent activity, during which he is next to the children and engages in their activities when necessary by increasing their knowledge and providing new challenges. Moreover, teacher helps children in learning how to cooperate, come to an agreement and solve disputes. Well-equipped and well-organised environment with all the necessary materials allows avoiding tricky situations, when the pedagogue is continuously busy with looking for materials and giving them out instead of productive cooperation with the child. By noting child's interests and needs, pedagogue trusts the child and accepts his ideas. 


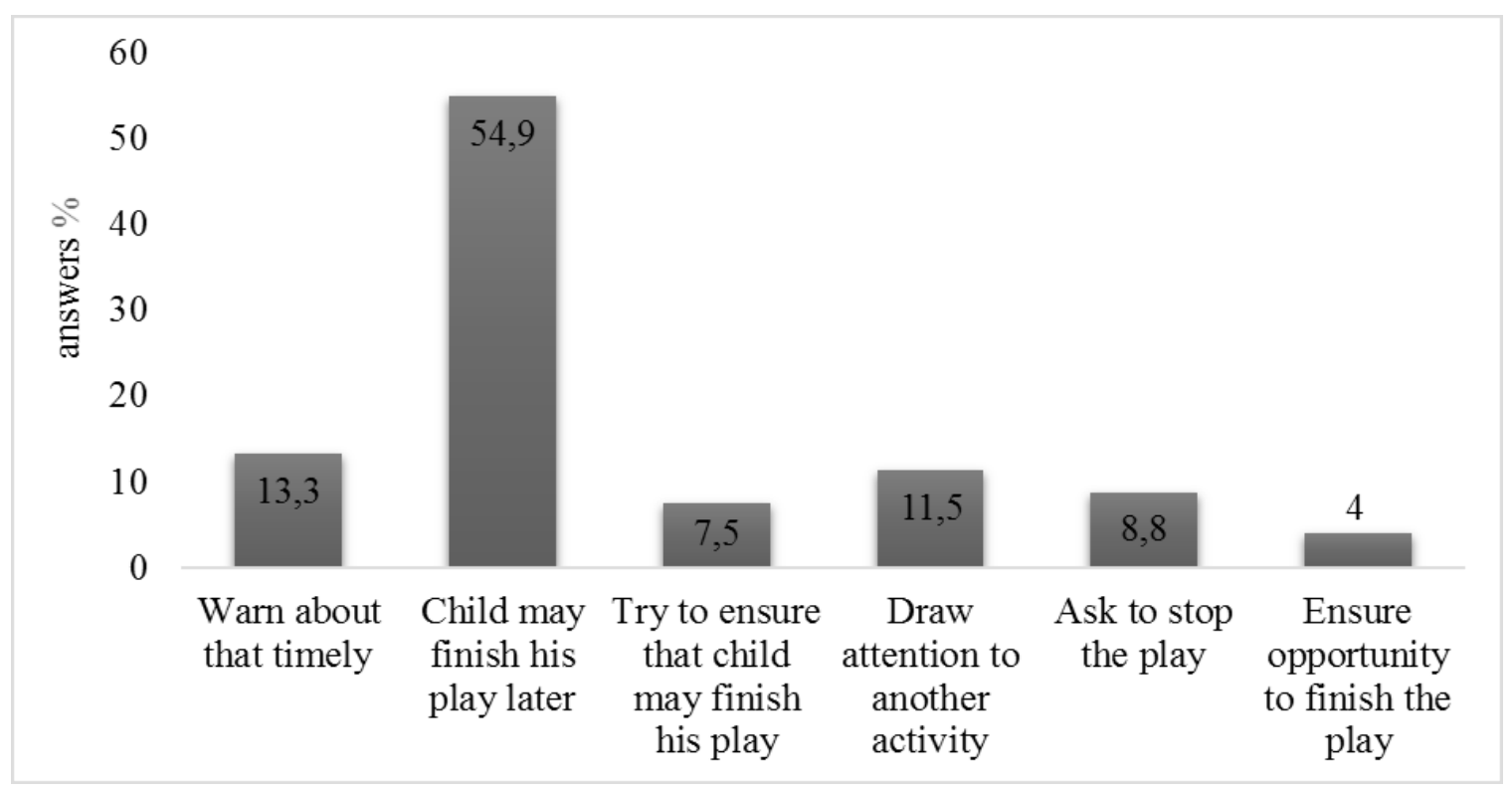

Figure 2. Actions of pedagogues if child has to stop his play

Of the respondents, $11.5 \%$ pointed out that they stop free, spontaneous activity of the child by drawing attention to another activity. By trying to engage all children, stopping children activities, pointing out what child should learn or do, the pedagogue prevents children from making decisions. If child is thought to obey already from childhood, he lacks the courage to start something new on his own, without endorsement or help from an authority, as it has been pointed out by M. Montessori. The pedagogue teaching the child that there is no such 'I want' is laying foundations to personality depending upon decision of other persons (Montessori, 1965). Out of all respondents, 54.9\% admitted that 'choose impact/effect strategy' (Šteinberga, Tunne, 1999, 19). It means making decisions instead of child (by allowing finishing the play later), nevertheless, 'the real joy comes from engaging in activities the child is really interested in' (Pêtersons, 1931, 27). When the child does not feel himself as the initiator of own acts, activities, does feel like being regulated and guided, he does not feel the joy for own activities (I. Opis, P. Opis, 1965; Geidžs, Berliners, 1998). Apart from giving the child joy, an engrossing, interesting activity that is not imposed by the teacher also serves as a base for the development of independent and responsible personality.

In the study, $8.8 \%$ of the respondents admitted that teaching the child to stop the play is done with an aim to initiate common, pragmatic daily activity (play-based lesson). By disabling the child from finishing his play or game, play activity loses its essence; habit to finish what has been started is not developed, and the child does not feel the joy that arises from successful accomplishment of the task, and thus development of the child is not encouraged. Already O. Svenne emphasised that teacher with his individuality should not suppress activity of the child; within the activity he has chosen, child should see new perspectives for independent actions (Svenne, 1930, 92).

Play is closely related to the cognition motive, which is the second most important pre-condition for meaningful learning. Theoretical researches (Greenwood, Walker, Carta, Higgins, 2006) show that playbased learning gives the child experience and skills necessary for successful school years, whereas planand material-based learning does not lay foundation for future academic success.

In practice, it may be often observed that pedagogues plan child activities already when he enters the room, e.g., by offering worksheet with certain, in teacher's opinion, targeted task. To find out motivation of the pedagogues for using worksheets, a questionnaire was drawn up. Pre-school teachers (totally 43) answered about the use of worksheets, usefulness and aim thereof, as well as motivation for using them. The survey results indicate that pedagogues use worksheets with an aim to test $(8 \%)$ and strengthen $(60 \%)$ children's knowledge. Only $4 \%$ of the respondents admitted that they offer children worksheets if they 
are interested in that. Answers to the question on co-operation between teacher and child when filling in the worksheets revealed that it is dominated by the direct guidance $(73 \%)$, which is based on guidelines, suggestions and explanations, 'telling what to do'. Out of the total number of respondents, $35 \%$ mentioned that they use worksheets during lessons, while $61 \%$ of the pedagogues admitted that they use worksheets outside lessons, thus reducing child opportunities to engage in a play (that is rather minimal). A summary of the results leads to the question - are worksheets related to the child's real life? Through individual discussions held with 60 children at older pre-school age during activities with the worksheets, it was found out that child does not understand the meaning of this activity. Children's answers are summarised in the Figure 3.

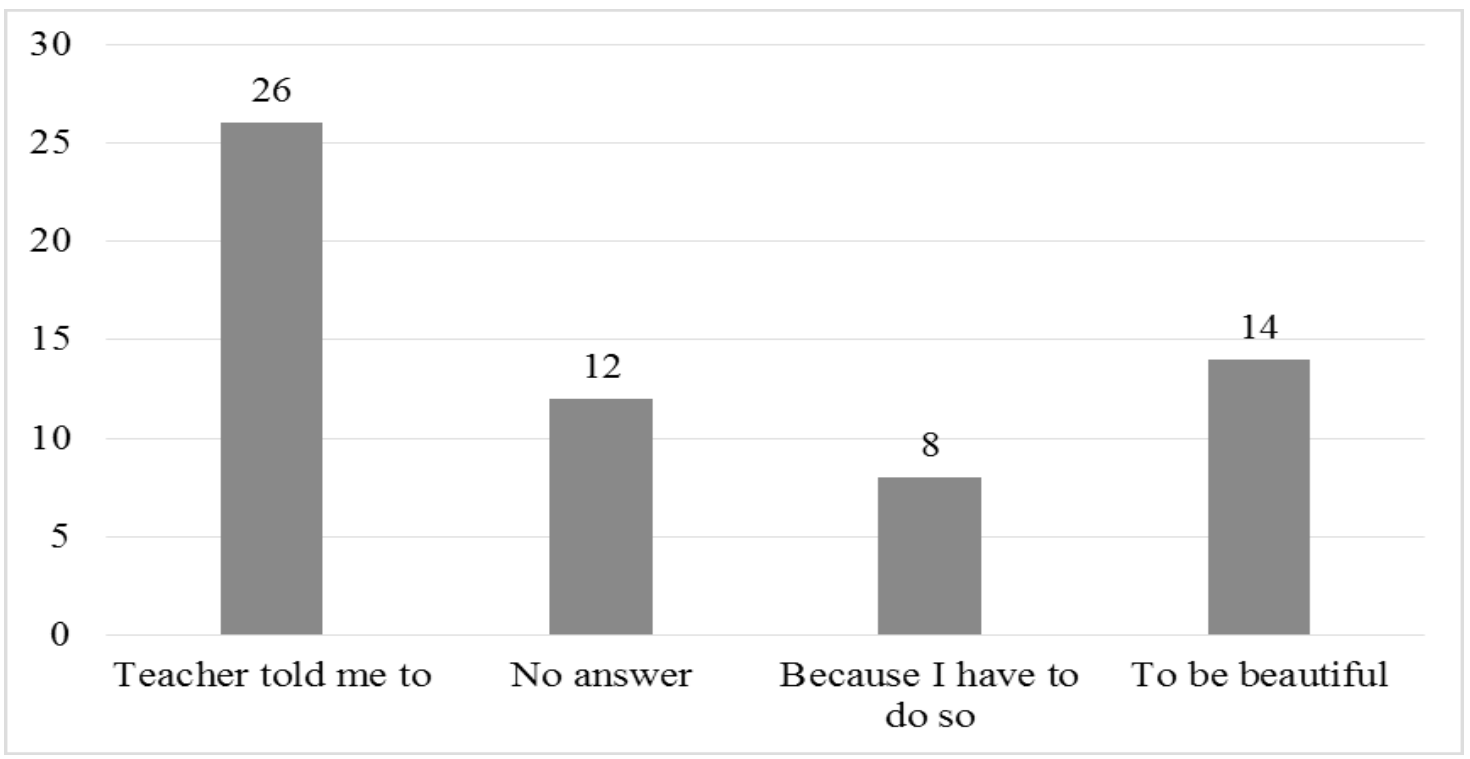

Figure 3. Understanding of the task given among pre-schoolers at older age

If a child understands that many unfamiliar, unknown and not quite understandable things have to be learned, he loses his interest and willingness to engage in the activity, and he is not motivated to engage in the activity. A child has a natural willingness to be active, cognise as well as inclination towards selforganisation and purposefulness. Are lessons planned in a way to ensure that this joy of activity, investigation and discoveries are not stifled? What are the things to which specific attention should be devoted? To avoid receiving answers 'teacher made me to', 'ask teacher', 'to be beautiful' or simply shrugging the question 'Why are you colouring/joining lines', learning should be implemented in a way to help child to realise, recognise his activity, to ensure that he has motivation, thus guaranteeing that the activity is meaningful.

It should be admitted that quite often children get ready, 'pre-fabricated' knowledge, thus ignoring child's willingness to create something new, acquire new knowledge via independent, meaningful activity (together with pedagogue, of course). Unfortunately, pre-school educational institution often is a place where the child gets information, but it is not related to real life. Only the pedagogue may give or withhold (not give) meaningful knowledge that child may use now and not sometime later. Curriculums include amount and volume of information to be acquired in pre-school, but it is impossible to include attitude, enthusiasm, benevolence or additional, extra knowledge of the pedagogue in it. Bearing in mind that the pace of life is becoming faster and volume of information increases, the pedagogue should help the child to learn how to think, investigate and analyse instead of teaching to accomplish the tasks given mechanically; therefore, only pedagogues knowing how to work creatively and freely are able to give child the most important lesson - to teach how to learn. 


\section{Conclusions}

The difference between the theoretical findings and practice is high. Learning in pre-school should take place gradually, gently, at ease and it should be interesting. The practice shows that topical interests and needs of pre-schoolers are not met; moreover cognitive activity of children is not facilitated through meaningful and purposeful action.

The child at a pre-school age should not acquire certain amount of knowledge. Learning how to observe the world, desire to find out about what is around us and express one's feelings and thoughts in words, movements and games is what really matters.

Playing for children is natural, unconstrained and meaningful activity allowing child to fell that he belongs somewhere, develop physically, socially and intellectually. Play is the most appropriate learning activity for a pre-schooler, since he may acquire the best education in it.

In the era of information and technologies, the pedagogue should be inclined to help the child in investigation, cognition, analysis and thus thinking instead of simply giving information and increasing theoretical knowledge.

\section{References}

Bazens, T. (2008). Efektīvas mācīšanās rokasgrāmata [Manual for Effective Learning]. Rīga: Jānis Roze. (in Latvian) Eriksons, H. E. (1998). Identitāte: jaunība un krīze [Identity: Youth and Crisis]. Rīga: Jumava. (in Latvian) Geidžs, N.L., Berliners, D. C. (1999). Pedagoǵiskā psiholoǵija [Pedagogical Psychology]. Rīga: Zvaigzne ABC. (in Latvian) Geist, E. (2009). Children are born mathematicians. Upper Saddle River: Pearson Education.

Greenwood, C. R., Walker, D., Carta, J. J., \& Higgins, S. (2006). Developing a general outcome measure of growth in the cognitive abilities of children 1 to 4 years old: The Early Problem-Solving Indicator. School Psychology Review, 35(4), 535-551.

Lieǵeniece, D. (1992). Bērns pasaulē - pasaule bērnā [Child in the World - World in the Child]. Rīga: Zvaigzne. (in Latvian) Ministru kabineta noteikumi Nr.533 [Regulations No 533 of the Cabinet] (2012). Noteikumi par valsts pirmsskolas izglitīibas vadlīnijām (Regulation on the State Preschool Education Guidelines). Retrieved 12.04.2015 from http://www.likumi.lv/ doc.php?id=250854 (in Latvian)

Montessori, M. (1965). The Advanced Montessori Method. India, Madras: Kalakshetra Publications. Opie, I. \& Opie, P. (1969). Children's games in street and playground. Oxford: Oxford University Press. Pētersons, E. (1931). Vispārīgā didaktika [General Didactics]. Rīga: Gulbis. (in Latvian) Svenne, O. (1930). Modernie audzināšanas jautājumi [Modern Upbringing Issues]. Rīga: Valters un Rapa. (in Latvian) Šteinberga, A., Tunne, I. (1999). Jauniešu pašizjūta un vērtības [Self-feeling and Values of Youth]. Rīga: RaKa. (in Latvian) Бордовская, Н. В., Реан, А. А. (2006). Педагогика [Pedagogy]. Издательство Питер. (in Russian)

Вилюнас, В. К. (1990). Психологические механизмы мотивачии человека [Psychological Mechanisms of Human Motivation]. Москва: Изд-во Моск. ун-та. (in Russian)

Выготский, Л. С. (2003). Психология развития человека [Psychology of Human Development]. Москва: Эксмо. (in Russian) Lecturer, Mg.paed., Ligita Priede, Riga Teacher Training and Educational Management Academy, Tērbatas iela 54-5, Riga, Latvia, telephone: (+371) 26179007, e - mail: dagnija.vigule@rpiva.lv.

University lecturer, Dr.paed., Dagnija Vigule, Riga Teacher Training and Educational Management Academy, Grants iela 11, Engure, Latvia, telephone: (+371) 29134066, e - mail: dagnija.vigule@rpiva.lv. 